\title{
Faktor-faktor Prognosis Kematian Tetanus Neonatorum di RS Kabupaten Indramayu dan Kabupaten Cirebon
}

\author{
Lili Tantijati* Krisnawati Bantas**
}

\begin{abstract}
Abstrak
Angka Kematian Bayi (AKB) di Indonesia masih tetap tinggi. Berdasarkan Biro Pusat Statistik (BPS) pada tahun 1995 adalah 55/1000 kelahiran hidup. Salah satu penyebab utama dari kematian bayi adalah penyakit tetanus neonatorum . Tujuan dari penelitian ini adalah untuk menentukan hubungan antara usia saat ditemukan adanya indikasi penyakit neonatarum pada bayi dengan timbulnya kematian yang disebabkan oleh tetanus neonatorum pada bayi-bayi tersebut di Kabupaten Indramayu pada tahun 1996-2001. Penelitian ini menggunakan disain studi epidemiologi kasus-kontrol dengan perbandingan kasus dan control 1:1. Jumlah sampel, 160 penderita tetanus neonatorum. Populasi studi adalah penderita tetanus neonatorum yang dirawat di RSD kabupaten Cirebon dan kabupaten Indramayu tahun 1996 - 2001. Variabel-variabel yang diteliti adalah variabel kematian (sebagai variable terikat), dan variabel usia neonatus saat onset penyakit, status kekebalan neonatus, berat lahir neonatus, kecepatan pertolongan, jenis, dosis, dan cara pemberian antibiotika; jenis, dosis, dan cara pemberian obat anti kejang dan cara pemberian ATS (sebagai variabel bebas). Semua variabel yang diteliti diukur dengan skala kategorikal. Analisis yang dilakukan secara bertahap meliputi analisis univariat, bivariat dan multivariat. Analisis multivariat menggunakan analisis regresi logistik. Hasil penelitian menunjukkan bahwa faktor-faktor prognosis kematian tetanus neonatorum adalah: usia penderita tetanus neonatorum $\leq 7$ hari $(O R=20.06$; nilai $p=0.000)$, dosis obat antibiotik yang lebih rendah dari standard $(O R=4.34$; nilai $p=0.018)$, kecepatan pertolongan oleh fasilitas kesehatan $\geq 2$ hari $(O R=6.95$; nilai $p=0.000$ )
\end{abstract}

Kata kunci: Faktor prognosis, kematian tetanus neonatorum.

\footnotetext{
Abstract value $=0.000$ )

Key words: Prognosis factor, tetanus neonatorun death

${ }^{*}$ Staf Dinas Kesehatan Kabupaten Indramayu **Staf Pengajar Departemen Epidemiologi Fakultas Kesehatan Masyarakat Universitas Indonesia
}

The Infant Mortality Rate (IMR) in Indonesia is still high. Based on Central Bureau of Statistics (CBS) data, the IMR in 1995 was 55/1000 live births. One of the main causes of infant death in Indonesia is tetanus neonatorum. The objective of this study was to determine the relationship between neonates' age of disease onset and the infant death caused by tetanus neonatorum in Indramayu and Cirebon Districts in 1996-2001. The study design was casecontrol study with ratio of the number of cases and control of 1:1. The total number of sample was 160 neonates with tetanus neonatorum, consisted of 80-cases(death) and 80-control (live). The study population was neonates with tetanus neonatorum who were hospitalized in Cirebon and Indramayu District Hospital. All of the study variables were measured using categorical scale. Study was analyzed by multivariate analysis, using unconditional logistic regression method. The result of the study showed that the prognostic factors of tetanus neonatorum death risk were age $\leq 7$ days old $(O R=20.06 ; p$ value $=0.000)$, neonates with lower than standard dose of antibiotics $(O R=4.34 ; p$ value $=0.018)$; delay of help by health facilities $\geq 2$ days $(O R=6.95 ; p$ 
Tetanus neonatorum adalah penyakit yang disebabkan Clostridium tetani. Penyakit yang terjadi pada masa neonatal (bayi usia $<28$ hari) masih merupakan penyebab utama kematian neonatal di negara berkembang termasuk Indonesia. Penyakit ini merupakan kausa kedua kematian penyakit yang dapat dicegah dengan imunisasi. Menurut WHO, meski sistem surveilens telah berjalan cukup baik, tetapi diperkirakan hanya mampu mencatat sekitar 5\% kasus tetanus neonatorum. Oleh sebab itu, penyakit ini disebut sebagai the silent killer. ${ }^{1}$ Case Fatality Rate (CFR) tetanus neonatorum sangat tinggi. Semakin singkat masa inkubasi semakin ganas penyakit ini. Kasus-kasus dengan masa inkubasi singkat yang tidak dirawat, hampir dipastikan angka fatalitas tersebut mendekati $100 \%$.

Hasil Survey Kesehatan Rumah Tangga (SKRT) tahun 1986 dan 1992 menunjukkan bahwa penyakit tetanus neonatorum yang dapat dicegah dengan imunisasi selalu berada pada kelompok 3 besar penyebab kematian bayi di Indonesia. Penyakit tersebut merupakan penyebab utama kematian neonatal. ${ }^{2}$ Di Jawa Barat, pada periode 1998 - 1999, Case Fatality Rate (CFR) tetanus neonatorum, mengalami penurunan yang tajam dari $22,5 \%$ menjadi $9,8 \%{ }^{3}$ Hal tersebut diduga sebagai akibat perbaikan dalam penatalaksanaan kasus, meskipun demikian, berdasarkan rekapitulasi laporan kasus tetanus neonatorum, Kabupaten Indramayu dan Kabupaten Cirebon, ternyata masih memperlihatkan angka kematian tetanus neonatorum yang tinggi. Pada tahun 2001, jumlah kematian tetanus neonatorum di RS Kabupaten Indramayu dan Kabupaten Cirebon adalah 9 dan 4 kasus dengan CFR $22.2 \%$ dan 25,0\%.

Ada berbagai faktor yang mempengaruhi kematian akibat penyakit tetanus neonatorum. Faktor tersebut antara lain meliputi usia bayi, status imunisasi TT ibu hamil, berat lahir neonatus, kecepatan pertolongan rumah sakit, jenis, dosis dan cara pemberian obat antibiotik, jenis, dosis dan cara pemberian obat anti kejang, serta cara pemberian ATS. Penelitian ini bertujuan untuk melihat hubungan berbagai faktor prognosis tersebut terhadap kematian akibat tetanus neonatorum.

\section{Metode}

Penelitian ini menggunakan desain penelitian epidemiologi kasus kontrol dengan pertimbangan relatif mudah, murah dan sederhana, mengingat keterbatasan jumlah subjek yang akan diteliti. Populasi penelitian adalah penderita tetanus neonatorum yang dirawat di rumah sakit umum daerah di wilayah kabupaten Cirebon dan Kabupaten Indramayu. Jumlah sampel pada penelitian dihitung dengan menggunakan rumus sampel minimal pada desain studi kasus kontrol. ${ }^{4}$ Dengan tingkat kepercayaan 95\%, tingkat kekuatan penelitian $80 \%$; proporsi bayi tetanus neonatorum yang bertahan hidup 0.20 dan nilai OR ditentukan $2.5 .^{5}$ Didapatkan jumlah sampel minimal untuk kasus dan kontrol masingmasing 79 orang subjek. Pada penelitian ini, jumlah seluruh subyek yang disertakan dalam penelitian ada 80 kasus dan 80 kontrol. Kasus dan kontrol adalah neonatus (umur $3-28$ hari) penderita tetanus yang dirawat dan tercatat pada Form T2 dan medical record rumah sakit Kabupaten Indramayu dan Kabupaten Cirebon pada periode Januari 1996- Desember 2001. Kasus adalah penderita tetanus neonatorum yang meninggal, sedangkan kontrol adalah penderita tetanus neonatorum yang bertahan hidup. Variabel-variabel yang diteliti meliputi variabel kematian (sebagai variabel terikat), usia neonatus (diukur dengan status imunisasi TT ibu), berat badan lahir, status kekebalan neonatus, kecepatan pertolongan oleh fasilitas kesehatan, jenis dosis dan cara pemberian antibiotik, jenis dosis dan cara pemberian anti kejang, dan pemberian ATS (sebagai variabel bebas).

\section{Hasil}

\section{Distribusi Berdasarkan Rumah Sakit}

Pada periode 1996-2001, jumlah seluruh penderita tetanus neonatorum yang dirawat di RS Umum Kabupaten Indramayu adalah 86 kasus (53.7\%), sedangkan yang dirawat di kabupaten Cirebon penderita tersebar di 3 rumah sakit umum pemerintah yaitu Rumah Sakit Gunung Jati (29 kasus; 18.1\%), Rumah Sakit Arjawinangun (37 kasus; 23.1 $\%$ ) dan Rumah Sakit Waled (8 kasus; $5.0 \%$ ) (Lihat tabel 1). Analisis Bivariat

Tabel 1. Kasus Tetanus Neonatorum Menurut Rumah Sakit

\begin{tabular}{lcc}
\hline \multirow{2}{*}{ Rumah Sakit } & \multicolumn{2}{c}{ Kasus } \\
\cline { 2 - 3 } & $\mathrm{N}$ & $\%$ \\
\hline RSU Indramayu & 86 & 53,8 \\
RSU Gunung Jati & 29 & 18,1 \\
RSU Arjawinangun & 37 & 23,1 \\
RSU Waled & 8 & 5,0 \\
\hline Total & 160 & 100,00 \\
\hline
\end{tabular}

Analisis bivariat dilakukan untuk mencari variabel kovariat yang akan masuk dalam model multivariat dengan kriteria nilai $\mathrm{p}$ uji statistik chi square adalah $\leq 0,25$. Variabel yang memenuhi kriteria tersebut adalah usia neonatus, kecepatan pertolongan RS, dosis anti kejang dan cara pemberian (Lihat tabel 2).

\section{Analisis Multivariat}

Pada analisis multivariat ditemukan bahwa variabel usia neonatus, dosis obat antibiotik dan kecepatan pertolongan berhubungan secara bermakna dengan kematian tetanus neonatorum (Lihat tabel 3).

\section{Uji Interaksi}

Uji interaksi dilakukan terhadap semua variabel yang terpilih ikut dalam model akhir analisis regresi logistik multipel. Dari uji interaksi, tidak ada satu variabelpun 
Tantijati dan Bantas, Faktor Prognosis Kematian Tetanus Neonatorum

Tabel 2. Rangkuman Analisis Bivariat untuk Seleksi Kandidat Variabel dalam Model Analisis Multivariat

\begin{tabular}{lllll}
\hline Variabel & Katagori & OR & Nilai p & $\mathbf{9 5 \%}$ CI OR \\
\hline Usia & $\leq 7$ hari & 16,8 & $0,000^{* *}$ & $097-37.82$ \\
Berat Badan Lahir & BBLR & 2,02 & $0,568^{*}$ & $0,18-22,80$ \\
Status TT Ibu & Tak lengkap & 1,36 & 0,388 & $0,73-2,51$ \\
Kecepat pertolong RS & $\geq 2$ hr & 6,59 & $0,000^{* *}$ & $2,69-16,71$ \\
$\begin{array}{l}\text { Obat Antibiotik } \\
\text { Jenis }\end{array}$ & Ampisillin & 1.10 & 0,539 & $0,55-1,06$ \\
& Kombinasi & 0,78 & 0,752 & $0,34-1,74$ \\
Kombinasi & Tunggal & 1,29 & 0,539 & $0,57-2,89$ \\
Cara Pemberian & Diganti & 1,53 & 0,361 & $0,61-3,81$ \\
Anti Kejang & & & \\
Jenis1 & Phenobarbital & 1,48 & 0,336 & $0,63-3,45$ \\
& Kombinasi & 1,17 & 0,69 & $0,54-2,54$ \\
Jenis2 & Tunggal & 0,93 & 0,85 & $0,44-2,0$ \\
Dosis Obat & <standar & 2,21 & $0,160^{* *}$ & $0,73-6,67$ \\
& >standar & 0,39 & 0,015 & $0,19-0,84$ \\
Cara Pemberian & Diganti & 0,77 & & $0,27-2,64$ \\
ATS & Cara1 & 2,89 & $0,011^{*}$ & $1,28-2,64$ \\
& Cara2 & 1,81 & 0,139 & $0,83-3,95$ \\
\hline
\end{tabular}

Keterangan : $\quad$ OR=Odds Ratio $\quad \mathrm{Cl}=$ Confindence Interval $\quad \mathrm{p}=$ nilai

Tabel 3. Hasil Analisis Regresi Logistik Multivariat Akhir

\begin{tabular}{|c|c|c|c|c|c|c|c|}
\hline \multirow[t]{2}{*}{ Variabel } & \multicolumn{2}{|c|}{ Kasus } & \multicolumn{2}{|c|}{ Kontrol } & \multirow{2}{*}{$\begin{array}{c}\text { OR } \\
\text { Adjusted }\end{array}$} & \multirow[t]{2}{*}{ p } & \multirow[t]{2}{*}{ 95\% CI } \\
\hline & $\mathbf{N}$ & $\%$ & $\mathbf{N}$ & $\%$ & & & \\
\hline \multicolumn{8}{|l|}{ Usia Neonatus } \\
\hline$<=7$ hari & 71 & 88.75 & 26 & 32.50 & 20.068 & 0.000 & $7.707-52.249$ \\
\hline$>7$ hari & 9 & 11.25 & 54 & 88.75 & 1.00 & References & \\
\hline \multicolumn{8}{|l|}{ Dosis Obat Antibiotik } \\
\hline Lebih rendah dari standar & 32 & 26.25 & 11 & 13.75 & 4.34 & 0.018 & $1.383-13.646$ \\
\hline Lebih tinggi dari standar & 9 & 11.25 & 10 & 12.50 & 1.14 & 0.862 & $0.331-4.099$ \\
\hline Sesuai & 50 & 62.50 & 59 & 73.75 & 1.00 & References & \\
\hline \multicolumn{8}{|l|}{ Kecepatnya Pertolongan } \\
\hline$>=2$ hari & 73 & 91.25 & 49 & 61.25 & 6.95 & 0.000 & $2.378-20.340$ \\
\hline 1 hari & 7 & 8.75 & 31 & 38.75 & 1.00 & References & \\
\hline
\end{tabular}

Keterangan : $\quad C I=$ Confindence Interval $\quad O R=O d d s$ Ratio

Tabel 4. Uji Interaksi Variabel Independen pada Model Terpilih

\begin{tabular}{lccc}
\hline Variabel Interaksi & Log Likehood & G & P \\
\hline $\begin{array}{l}\text { Usia Neonatus, Dosis Obat Antibiotik, Cepatnya pertolongan RS, } \\
\text { tanpa variabel interaksi }\end{array}$ & -71.611274 & & \\
$\begin{array}{l}\text { Usia Neonatus, Dosis Obat Antibiotik, Cepatnya pertolongan RS, } \\
\text { dengan inter 1 (Usia Neonatus*epat) }\end{array}$ & -71.567143 & 0.088 & 0.761 \\
$\begin{array}{l}\text { Usia Neonatus, Dosis Obat Antibiotik, Cepatnya pertolongan RS, } \\
\text { dengan inter 1 (Usia Neonatus*Dosis antibiotik) }\end{array}$ & -70.931132 & 1.399 & 0.265 \\
\hline
\end{tabular}

Ket: Bila $\mathrm{p}<0.05$ ada interaksi. Pada tabel diatas tidak ada interaksi $(\mathrm{p}>0.05)$

G: -2 Log Likehood

yang beriteraksi, dilihat dari nilai $\mathrm{p}$ variabel interaksi $>0.05$ (pada tabel 4).

\section{Faktor yang Berhubungan}

\section{Usia Neonatus.}

Berdasarkan analisa multivariat, terlihat hubungan yang bermakna antara usia neonatus dan kematian tetanus neonatorum. Penderita tetanus neonatorum yang berusia 7 hari atau kurang berisiko 20.1 kali lebih besar untuk meninggal dunia dari pada penderita tetanus neo- natorum yang berusia lebih dari 7 hari (OR:20.06; 95\% CI : 7.707-52.249). (Tabel 3). Masa inkubasi tetanus neonatorum berkisar 3-28 hari. Masa inkubasi yang kurang dari 7 hari tampaknya lebih parah daripada yang sama atau lebih dari 7 hari. Hasil penelitian ini sesuai dengan penelitian Hardewo dan Sutedjo di RSUD DR Soetomo Surabaya tahun 1985. Penderita tetanus neonatorum yang berusia 7 hari atau kurang berisiko meninggal dunia lebih tinggi $(83.3 \%)$ dari pada bayi yang berusia lebih dari 7 hari $(25 \%){ }^{6}$ 


\section{Kecepatan Pertolongan.}

Pada analisis multivariat, penderita tetanus neonatorum yang dibawa ke rumah sakit 2 hari atau lebih setelah gejala pertama berisiko meninggal dunia 6.9 kali lebih besar daripada yang dibawa ke rumah sakit pada hari pertama (OR:6.95 ; 95\% CI: 2.378-20.340). Temuan ini sesuai dengan studi yang dilakukan di kabupaten Indramayu tahun 1994-2000, bahwa penderita tetanus neonatorum yang dibawa ke fasilitas pelayanan kesehatan 24 jam atau lebih berisiko 31.6 kali lebih besar untuk meninggal dunia daripada yang dibawa ke fasilitas pelayanan kesehatan kurang dari 24 jam. ${ }^{5}$ Pada "Tata Laksana Bayi Sakit 1-2 bulan" dinyatakan bahwa setiap bayi dengan demam $\left(>37.5^{0} \mathrm{C}\right)$ harus segera dirujuk ke rumah sakit. ${ }^{7}$ Fatalitas penderita pertolongan penyakit tetanus neonatorum sangat tinggi karena biasanya baru mendapat pertolongan jika keadaan bayi telah gawat. Pasien-pasien tetanus neonatorum perlu segera dirawat ke rumah sakit, karena membutuhkan pengawasan dan perawatan yang ketat karena sering timbul komplikasi seperti bronko pneumonia, asfiksia, sianosis akibat obstruksi pernafasan. ${ }^{8}$ Kematian kasus tetanus neonatorum dipengaruhi oleh kecepatan pertolongan dan kemampuan fasilitas pelayanan yang memberikan pertolongan.

\section{Dosis Obat Antibiotik}

Dalam analisis multivariat, ternyata dosis antibiotik lebih rendah dari standar berhubungan secara bermakna dengan kematian tetanus neonatorum $(\mathrm{OR}=4.34 ; 95 \%$ CI :1.38-13.6). Sedangkan untuk yang mendapat dosis yang tinggi tidak memperlihatkan hubungan yang bermakna (OR:1.14 ; 95\% CI : 0.331-4.099). Hasil penelitian ini sesuai dengan anjuran bahwa Penisilin G diberikan dengan dosis $50.000 \mathrm{IU} / \mathrm{kg} / \mathrm{hari},{ }^{9}$ untuk pasien-pasien tetanus neonatorum.

\section{Variabel yang Tidak Berhubungan \\ 1. Berat Badan Lahir}

Pada analisis bivariat, berat lahir rendah (BBLR) tidak berhubungan secara bermakna dengan kematian akibat tetanus neonatorum (nilai $\mathrm{p}=0.56$ ). Variabel ini tidak disertakan sebagai kandidat model multivariat. Temuan ini berbeda dengan temuan penelitian sebelumnya, bahwa bayi BBLR berisiko 5-9 kali lebih tinggi daripada bayi dengan berat lahir normal. Perbedaan tersebut kemungkinan disebabkan oleh jumlah penderita tetanus neonatorum dengan BBLR yang terlalu kecil (3 dari 160 subyek penelitian). Satu kasus yang bertahan hidup adalah yang segera mendapat pertolongan RS. Faktor lain yang mempengaruhi kematian yang tinggi pada bayi BBLR adalah asfiksia.

\section{Kekebalan Neonatus}

Penelitian ini menemukan bahwa bayi dari ibu yang telah mendapat imunisasi TT lengkap masih berisiko mengalami penyakit tetanus neonatorum. Temuan ini sesuai dengan penelitian Ratgono di kabupaten Tanggerang tahun 1990 yang menyatakan bahwa bayi dari ibu dengan status imunisasi TT yang tidak lengkap berisiko 4 11 kali lebih besar untuk menderita tetanus neonatorum daripada bayi dengan status imunisasi TT ibu yang lengkap. ${ }^{10,11}$ Titer antitoksin tetanus toxoid pada daerah tali pusat dan darah ibu, di Uganda, pada dosis tunggal dan dua kali suntikan, adalah lebih rendah dari pada dosis dua kali suntikan. ${ }^{12}$ Hasil penelitian ini tidak memperlihatkan hubungan yang bermakna antara kekebalan bayi dengan kematian akibat tetanus neonatorum (OR:1.36 ; 95\% CI :0.725-2.550). Kekebalan yang diperoleh dari ibunya lewat imunisasi TT tidak berpengaruh terhadap kematian neonatus tetapi berpengaruh terhadap kejadian tetanus neonatorum. Bayi dengan ibu yang telah diimunisasi lengkap ternyata masih terkena tetanus neonatorum. Hal ini kemungkinan disebabkan oleh bias ingatan, ibu penderita tetanus neonatorum lupa tentang waktu imunisasi TT1 dan TT2. Dosis pemberian yang tidak sesuai dan jarak waktu pemberian yang tidak sesuai dengan ketentuan dapat menyebabkan imunisasi TT tidak efektif.

Kekebalan neonatus tidak berpengaruh terhadap kematian tetanus neonatorum. Hal ini sesuai dengan penelitian di Colombia, bayi penderita tetanus neonatorum dengan ibu yang memperoleh suntikan dosis tunggal (TT1) dan yang memperoleh suntikan dosis dua kali (TT2) tidak memperlihatkan perbedaan risiko kematian. ${ }^{13}$

\section{Jenis Obat Antibiotik}

Jenis obat antibiotik tidak berhubungan bermakna dengan kematian tetanus neonatorum. Penderita mendapat obat ampicilin berisiko meninggal dunia sama besar dengan yang mendapat prokain penisilin (OR:1.10; 95\% CI :0.504-2.037 ). Hal yang sama ditemukan ada pemberian obat kombinasi, penderita yang mendapat antibiotik kombinasi (OR:0.78 ; 95\% CI: 0.315-1.941). Penelitian di Yugoslavia menemukan resistensi prokain penisillin hanya $10.5 \%$ dan sangat efektif untuk kuman gram positip. ${ }^{14}$ Harga prokain penisilin yang lebih murah dijadikan pertimbangan sebagai obat standar.

\section{Antibiotik Tunggal dan Kombinasi}

Kombinasi obat antibiotik tidak berhubungan bermakna dengan kematian tetanus neonatorum (OR: 1.29; 95\% CI : 0.574-2.891). Temuan ini sesuai dengan penelitian sebelumnya. ${ }^{13}$ Meskipun demikian, "Bagan Tata Laksana Bayi Muda untuk Infeksi Berat dengan Gangguan Pernafasan" menganjurkan pemberian antibiotik kombinasi penicilin dan gentamysin. ${ }^{15}$ Penelitian di Jerman menyatakan bahwa ampicilin efektif untuk bakteri gram positif dan bakteri gram negatif. Hal 
tersebut kemungkinan disebabkan oleh dosis tunggal dan kombinasi masih sama-sama efektif untuk kuman gram positif. Meskipun demikian, diperlukan penelitian dengan disain kohort atau studi intervensi dan jumlah sampel yang cukup besar untuk melihat pengaruh pemberian obat tunggal dan kombinasi.

\section{Cara Pemberian Antibiotik}

Penggantian antibiotik selama perawatan tidak memperlihatkan hubungan yang bermakna dengan kematian tetanus neonatorum (OR:1.53; 95\% CI: 0.6143.814). Penggunaan antibiotika di Indonesia mencapai $27 \%$ dari seluruh jenis obat dan pola penggunaan yang berlebihan banyak yang tidak tepat. Lama penggunaan dan frekuensi penggunaan antibiotik yang tinggi dapat menyebabkan resistensi kuman. Kasus tetanus neonatorum yang terjadi pada masa neonatal yang belum terpajan dengan antibiotik, sehingga pergantian jenis antibiotik ini tidak berpengaruh dan tidak banyak digunakan sehingga tidak memperlihatkan perbedaan yang bermakna.

\section{Jenis Obat Anti Kejang (1).}

Jenis obat anti kejang yang digunakan yaitu fenobarbital sebagai obat pilihan kedua dan diazepam sebagai obat pilihan pertama tidak berhubungan bermakna dengan kematian tetanus neonatorum (OR:1.48; 95\% CI:0.633-3.451). Hal yang sama juga ditemukan pada pemberian obat kombinasi (OR: 1.17 ; 95\%CI : 0.542-2.544). Penelitian di Perancis menemukan bahwa trismus pada tetanus akan membaik setelah 5 menit diberikan diazepam inteavenous infusion. ${ }^{16}$ Juga dalam buku "Bagan Tata Laksana Bayi Muda" dari Depkes yang menyatakan bahwa diazepam adalah obat anti kejang pilihan pertama yang mempunyai daya kerja yang cepat. ${ }^{7}$ Nelson ${ }^{9}$ juga menyatakan diazepam terbukti merupakan obat yang cukup efektif untuk mengendalikan hipertonisitas dan spasme. Tetapi penelitian di Canada menyatakan Fenobarbital juga efektif sebagai antikonvulsan dengan penggunaan rata-rata selama 5.8 hari dan efektif untuk neonatal. Hal yang sama ditemukan pada penelitian di New Zeland yang menyatakan fenobarbital efektif sebagai obat antikonvulsan pilihan setelah tahun 1990.17 Penelitian di Jerman menyatakan fenobarbital efektif untuk kasus pada neonatal sebagai antikonvulsant. ${ }^{18}$ Hubungan yang tidak bermakna tersebut kemungkinan disebabkan oleh efektifitas anti kejang tersebut sama. Meskipun demikian pilihan pada diazepan tetap beralasan karena harganya yang relatif murah. ${ }^{7}$ Obat anti kejang diberikan paling tidak selama 10 hari.

\section{Dosis}

Pada analisis bivariat penderita tetanus neonatorum yang mendapat anti kejang dengan dosis lebih rendah dari standar secara statistik tidak berhubungan bermakna (OR:2.21; 95\%CI: 0.731-6.667). Sedangkan yang diberikan dosis obat anti kejang yang lebih tinggi berisiko 0,39 kali lebih kecil untuk meninggal daripada pada yang mendapat dosis obat anti kejang yang sesuai standar (OR:0.39 ; 95\%CI: 0.187-0.837). Namun pada analisis multivariat tidak terlihat hubungan yang bermakna antara dosis obat anti kejang dengan kematian akibat tetanus neonatorum. Dosis obat anti kejang yang sesuai standar sesuai dengan dosis anti kejang dianjurkan oleh WHO dalam Management of Child With a Serious Infection or Severe Malnutrition. ${ }^{19}$

\section{Cara Pemberian}

Penelitian ini tidak menemukan hubungan yang bermakna antara penggantian anti kejang dengan kematian tetanus neonatorum. Penderita yang mengalami pergantian obat anti kejang (OR:0.84; 95\%CI: 0.271-2.637) (Tabel 5). Tata laksana bayi muda Depkes menyarankan bahwa diazepam merupakan obat anti kejang pilihan pertama dengan daya kerja yang relatif cepat dan fenobarbital adalah obat pilihan kedua. ${ }^{7}$ Namun, penelitian di Jerman menyatakan fenobarbital juga efektif untuk kasus pada neonatal sebagai antikonvulsant. ${ }^{18}$ Hubungan yang tidak bermakna tersebut kemungkinan disebabkan oleh fenobarbital dan diazepam sama efektif mengatasi kejang, sehingga penggantian anti kejang tidak berhubungan dengan kematian tetanus neonatorum.

\section{Cara Pemberian ATS}

Pada analisis bivariat, cara pemberian ATS tidak berhubungan secara bermakna dengan kematian tetanus neonatorum. Penderita tetanus neonatorum yang mendapat ATS cara 1 berisiko 2.89 kali lebih besar untuk meninggal dunia daripada yang diberikan ATS cara 0. (OR:2.89; 95\%CI:1.281-6.513). Sedangkan neonatus yang diberikan ATS cara 2 (pemberian ATS 10.000/hari selama 4 hari berturut-turut) dibandingkan yang diberikan ATS cara 0 secara statistik tidak ada hubungan bermakna dengan kematian akibat tetanus neonatorum (OR:1.81; 95\% CI : 0.825-3.949 ). Cara 0 adalah pemberian ATS10.000 IU/hari separuh intra muskuler dan separuh intravena selama 2 hari berturut-turut. Cara 1 adalah pemberian ATS 10.000u/hari dibagi 3 yaitu : $1 / 3$ intravena, $1 / 3$ intra muskuler, $1 / 3$ pusat. Cara 2 adalah pemberian ATS 10.000/hari selama 4 hari berturutturut. Namun pada analisis multivariat cara pemberian ATS tersebut tidak terlihat berhubungan secara bermakna dengan kematian tetanus neonatorum.

Nelson ${ }^{9}$ menganjurkan ATS diberikan dengan dosis sebesar $10.000 \mathrm{IU} /$ hari selama 2 hari. Antitoksin itu dibagi sama banyak setengah dosis intra muskular dan setengah lagi intravena. Pada dasarnya dosis ATS tetap 10.000 IU/hari, sehingga cara pemberian ATS setelah dikontrolkan variabel lain tidak memperlihatkan perbedaan secara bermakna. 


\section{Kesimpulan}

Faktor-faktor yang berhubungan dengan kematian penderita tetanus neonetorum di RS umum daerah di wilayah Cirebon dan Indramayu adalah umur penderita, dosis pemberian antibiotika dan kecepatan pertolongan. Penderita tetanus neonatorum yang berusia 7 hari atau kurang berisiko meninggal dunia jauh lebih besar daripada penderita yang berusia lebih dari 7 hari. Penderita tetanus neonatorum yang diberikan antibiotik dengan dosis yang lebih rendah berisiko meninggal dunia lebih besar daripada yang mendapat antibiotika yang sesuai protap. Penderita tetanus neonatorum yang dibawa ke rumah sakit setelah sakit 2 hari atau lebih setelah serangan, berisiko untuk meninggal dunia lebih besar daripada penderita yang segera dibawa ke rumah sakit.

\section{Saran}

1. Kepada dinas kesehatan untuk meningkatkan upayaupaya deteksi dini penderita tetanus neonatorum, sehingga dapat dirujuk secara cepat ke rumah sakit rujukan. Hal tersebut dapat dilakukan dengan cara menyebarluaskan informasi tentang gejala, tanda-tanda dan lokasi rumah sakit yang dapat memberikan pertolongan.

2. Kepada rumah sakit umum daerah disarankan untuk memberikan anti biotik dengan dosis yang tepat sesuai dengan panduan. Penderita-penderita tetanus neonatorum yang berusia kurang dari 7 hari perlu mendapat penanganan yang lebih intensif.

3. Kepada para peneliti ilmu kesehatan anak disarankan untuk melakukan uji klinik untuk menentukan secara lebih akurat tentang berbagai teknik dan metoda penata laksanaan tetanus neonatorum, guna meningkatkan efektifitas pelayanan kesehatan.

\section{Daftar Pustaka}

1. Word Health Organization. Field manual for manual tetanus elimenation. Depatermen of Vacinnes and other Biologicals, Geneva; 1999; 15 hal.

2. Departemen Kesehatan RI. Profil kesehatan indonesia 2000. Jakarta; 2000; 51 hlm.

3. Dinas Kesehatan Jawa-Barat. Profil kesehatan jawa barat 2000.
Indramayu; 2000; 171 hal.

4. Lameshow, S, et all. Besar sampel dalam penelitian kesehatan. Yogyakarta: Gajah Mada University Press; Cetakan I; 1977; 264 hal.

5. Tantijati. Hubungan cepatnya pertolongan penderita tetanus neonatorum dengan kematian neonatal pada penderita tetanus neonatorum di kabupaten indramayu tahun 1994-2000. Laporan MAPL Studi Observasional, FETP PPS FKMUI. 2000.

6. Hardewo L \& Sutejo H. Penelusuran terjadinya penyakit tetanus neonatorum pada bayi yang dirawat di RSUD dr. soetomo surabaya tahun 1985. Surabaya: Pusat Penelitian Pengembangan Pelayanan Kesehatan;1985: 29 hal.

7. Departemen Kesehatan RI. Pedoman operasional program imunisasi. Jakarta: Sub Direktorat EPIM-KESM Direktorat Jenderal Pemberantasan Penyakit Menular dan Penyebaran Lingkungan Pemukiman; 2001; 41 hal.

8. Wiknjosastro,H. Ilmu kebidanan. Jakarta: Yayasan Bina Pustaka Sarwono Prawirohardjo; 1999; 991 hal.

9. Nelson. Textbook of pediatry : anaerobic bacterial infection $16^{\text {th }}$ Edition. 2000; 881 hal.

10. Ratgono. Faktor-faktor resiko pada tetanus neonatorum, tanggerang 1988-1989. [Tesis]. Depok: Fakultas Ilmu Kesehatan Masyarakat Universitas Indonesia; 1990.

11. Kurniati,N. Identifikasi faktor-faktor resiko yang erat hubu ngannya dengan kejadian tetanus neonatorum di kabupaten serang tahun 19941995. [Tesis]. Depok: Fakultas Kesehatan Masyarakat Universitas Indonesia; 1996.

12. Standfield JP,et all. Single dose antenatal tetanus imunization, Lancet: Depaterment Of Pediatric and Child Health, Makarere University Uganda; 1973; $3: 215-219$.

13. Newell,et all. The use of toxoid for the prevention of tetanus neonatorum. Final report of the double blind Controlled Field Trial, International Center Of Medical Reseach and Training Columbia, Bulletin WHO;1966; 35 :863-871.

14. Tomovic, Mikrovic. Penicilin resistance in strain of staphylococus pneumonia. Yogoslavia: Vojnomedicin Aka demija, Zavud Za Preventiv Nu Medicine, Institut Za Mikrobiologija, Nosanit Kreg; 1996: 53( 3): 383 -384 .

15. Depatermen Kesehatan RI . Buku bagan tata laksana bayi muda umur 1 hari sampai 2 bulan. Jakarta; Ditjen Binkesmas; 20003; 2 hal.

16. Mayaud,C, et all. Trismus and tetanus vacine, service de pediatrie hospital andre-mmignot Lechisnag,France: 1999. Arch Pediatri Journal; 6 (7); 752-753.

17. Wallace SJ. Review of the adverse effects of anticonvulsant in children with epilepsi. 1996.

18. Kindergenesklude, et al. Treatment of convolsi in new born infant. Deutch: Ned Tjidscher-Geneeska; 1996; 140(30); 557:558.

19. World Heath Organization. Management of the child with a serious infection or severe malnutrition. Geneva: Departemen of Child and Adolescent Health and Development; 2000; 161 hal. 